\title{
NASTĘPSTWA ZMIANY SPOSOBU KORZYSTANIA Z NIERUCHOMOŚCI ODDANEJ W UŻYTKOWANIE WIECZYSTE WBREW CELOWI USTALONEMU W TREŚCI TEJ UMOWY ORAZ PRZEZNACZENIU GRUNTU WYNIKAJĄCYM Z MIEJSCOWEGO PLANU ZAGOSPODAROWANIA PRZESTRZENNEGO
}

\section{WPROWADZENIE}

Użytkowanie wieczyste jest instytucją prawna, której znaczenie dla obrotu prawnego, a zwłaszcza dla gospodarowania nieruchomościami, w ostatnich latach diametralnie się zmieniło. $\mathrm{Z}$ początku zadaniem użytkowania wieczystego było zapewnienie kontroli państwa nad obrotem nieruchomościami przez zachowanie własności państwowej nieruchomości, mimo trwałego korzystania $\mathrm{z}$ nieruchomości przez osoby trzecie ${ }^{1}$. $\mathrm{Z}$ tego też względu natura użytkowania wieczystego znajdowała się na granicy administracyjnoprawnej formy władania nieruchomościa przez organy administracyjne oraz cywilistycznej konstrukcji prawa rzeczowego. Fundamentalna zmiana w tej kwestii nastała po wejściu w życie Kodeksu cywilnego w 1965 r. i umiejscowieniu użytkowania wieczystego pomiędzy prawami rzeczowymi. Nie budzi już wątpliwości, że oddawanie nieruchomości gruntowej w użytkowanie wieczyste stanowi jeden z przejawów aktywności inwestycyjnej Skarbu Państwa i jednostek samorzą du terytorialnego $\mathrm{w}$ sferze dominium. W tym świetle umowa o oddanie nieruchomości w użytkowanie wieczyste zawierana jest pomiędzy, z założenia, równymi podmiotami zamierzającymi osiąnąć określony z góry cel gospodarczy. Z tego powodu doniosłe znaczenie ma kwestia wpływu stron na zmianę treści pierwotnie nawiązanego stosunku prawnego. Zatem podstawowym celem opracowania jest przedstawienie koncepcji prawnie dopuszczalnych reakcji właściciela gruntu oddanego w użytkowanie wieczyste przeciwko działaniom użytkownika wieczystego zmierzających do zmiany pierwotnie ustalonego celu tego stosunku prawnego. $\mathrm{Z}$ kolei osiagnięcie powyższego nastapi po rozstrzygnięciu następujących głównych problemów badawczych. Po pierwsze, określeniu znaczenia celu dla treści użytkowania wieczystego. Po drugie, ocenie wpływu czynności faktycznych podejmowanych przez użytkownika wieczystego na treść użytkowania wieczystego i wysokość związanych

${ }^{1}$ Rys. historyczny Woźniak (2006): 1-7. 
z tym prawem opłat. I wreszcie, kwalifikacji miejscowego planu zagospodarowania przestrzennego ${ }^{2}$ jako podstawowego aktu prawnego delimitującego zakres dopuszczalnych czynności prawnych podejmowanych przez strony tego stosunku prawnego.

\section{ZNACZENIE CELU DLA TREŚCI UŻYTKOWANIA WIECZYSTEGO}

Niewątpliwie charakterystycznym elementem treści użytkowania wieczystego jest cel tego stosunku prawnego, na który oddaje się grunt ${ }^{3}$. Jednakże wbrew temu założeniu język prawny, identyfikując użytkowanie wieczyste, wskazuje na inne konstytutywne pojęcia. Głównie chodzi o: 1) sposób korzystania, który w myśl art. 239 k.c. oraz 29 ust. 1 u.g.n. ${ }^{4}$ staje się jedynym z koniecznych elementów umowy; 2) sposób zagospodarowania odnoszący się w szczególności do zabudowy gruntu (art. 62 u.g.n.) oraz 3) przeznaczenie gruntu (art. 240 k.c.), którego naruszenie stanowi jedno z kryteriów pozwalających na rozwiązanie umowy przed upływem terminu ${ }^{5}$. Do „celu” użytkowania wieczystego (bądź zgodnie z art. 236 k.c. - „celu gospodarczego”) przepisy prawa odnoszą się wyłącznie pośrednio, wskazując, jak się wydaje, jego subsydiarne znaczenie. W głównej mierze „cel” stanowi kryterium współdecydujące o długości trwania użytkowania wieczystego (art. 29 ust. 1 u.g.n. i art. 236 k.c.) oraz współprzesądzające o terminie zabudowy nieruchomości (art. 62 ust. 1 u.g.n.). Cel użytkowania wieczystego nabiera natomiast pierwszorzędnego znaczenia dopiero przy określaniu wysokości stawek procentowych dla opłat rocznych (art. 72 ust. 3 u.g.n.). Z kolei głównym źródłem informacji o celu, a przez to i o innych wspomnianych elementach treści użytkowania wieczystego, jest umowa o oddanie gruntu w użytkowanie wieczyste. Nie dziwi więc, że umowa o oddanie gruntu w użytkowanie wieczyste, obok ustawy i zasad współżycia społecznego, wyznacza granice uprawnień użytkownika wieczystego. Implikuje to wniosek, że raz ustalony w umowie cel, na jaki oddaje

${ }^{2}$ Dalej: m.p.z.p.

${ }^{3}$ Cisek (2007): 175; Zbiegień-Turzańska (2015). Odnotować jednak należy pogląd uznajacy, że celowość użytkowania wieczystego nie jest elementem konstytutywnym dla tej instytucji, szczególnie dlatego, że celowość użytkowania wieczystego ma sprzyjać prowadzeniu gospodarki nieruchomościami, a nie ją ograniczać. Tak Truszkiewicz (2012): 16.

${ }^{4}$ Ustawa z 21 sierpnia 1997 r. o gospodarce nieruchomościami, t.jedn.: Dz. U. 2018, poz. 2204 (dalej jako: u.g.n.).

${ }^{5}$ Zaznaczona różnorodność pojęciowa doprowadziła do niespójności terminologicznej, która była wskazywana od początku obowiązywania u.g.n. zob. - Pyrzyńska (1998): 64-65. Przeznaczenie nieruchomości jest pojęciem obejmującym zarówno sposób korzystania z nieruchomości, jak i sposób i termin jej zagospodarowania oraz cel, na który nieruchomość została oddana w użytkowanie wieczyste, por. Truszkiewicz (2006): 178; (2012): 18; zob. wyrok SN z 29 czerwca 2007 r. (I CSK 133/07, Legalis), w którym starano się rozgraniczyć pojęcia celu i sposobu korzystania. Stwierdzono, że wobec braku definicji ustawowej znaczenie tych pojęć należy odtwarzać je na podstawie ich znaczenia językowego. W tym ujęciu cel jest to planowy wynik każdego racjonalnego działania, to do czego się dąży i o co się zabiega, a sposób to konkretna, określona metoda, forma lub tryb wykonania, ujęcia czegoś. 
się grunt w użytkowanie wieczyste, musi być respektowany przez strony, zaś jego zmiana - jako elementu treści tego stosunku prawnego - może się odbyć jedynie za ich zgodą ${ }^{6}$ Ostatecznie to bowiem treść umowy zadecyduje o sposobie wykonywania uprawnień przez użytkownika wieczystego, który będzie determinowany całokształtem okoliczności wpływających na cel albo szerzej: przeznaczenie tej relacji prawnej.

W tym świetle zauważalne jest powiązanie pomiędzy celem, na jaki oddaje się grunt, a określonym w umowie sposobem korzystania z tej nieruchomości jako elementami względem siebie komplementarnymi, a wręcz warunkującymi się wzajemnie ${ }^{7}$. Ścisły związek między sposobem korzystania a celem użytkowania wieczystego wyraża się w dwóch aspektach. Po pierwsze, chociaż $\mathrm{w}_{\text {poprzednim }}{ }^{2}$, jak i aktualnym ${ }^{9}$, stanie prawnym ujawnienie $\mathrm{w}$ księdze wieczystej postanowień umowy dotyczących sposobu korzystania z gruntu przez użytkownika wieczystego ma nadal charakter deklaratoryjny ${ }^{10}$, to sa one wiążące dla kolejnego nabywcy prawa użytkowania wieczystego ${ }^{11}$. W rezultacie nawet wtedy, gdy sposób korzystania z nieruchomości nie został w księdze wieczystej ujawniony, każdy kolejny nabywca prawa użytkowania wieczystego jest obowiązany wykonywać umowę zgodnie z jej treścia, a zatem przestrzegajacc celu tego stosunku prawnego ${ }^{12}$. Po drugie, w przypadku niemożliwości ustalenia celu użytkowania wieczystego - zawartego przed 1 stycznia 1998 r. - na podstawie konkretnych postanowień umownych decydujace znaczenie ma analiza faktycznych zachowań użytkownika wieczystego ${ }^{13}$. W pozostałych sytuacjach konieczne jest przeprowadzenie wykładni oświadczeń woli na podstawie art. 65 k.c. ${ }^{14}$ Taki sam zabieg należy zastosować w sytuacji, gdy umowa o oddanie gruntu w użytkowanie wieczyste określa więcej niż jeden cel dla wskazania, który z nich jest tym głównym (podstawowym).

Podkreślić należy również, że problematyka zmiany celu użytkowania wieczystego przez faktyczne działania samego użytkownika wieczystego nabrała niebagatelnego znaczenia przy gruntach oddanych w użytkowanie wieczyste

${ }_{6}$ Tak wyrok SN z 6 czerwca 2012 r., III CSK 289/11, Lex nr 1164290.

7 Wyrażono również pogląd, że w przypadku gdy nie wskazano w umowie sposobu korzystania z nieruchomości, uprawnienia użytkownika wieczystego w tym zakresie pokrywają się z uprawnieniami właściciela nieruchomości; zob. Sanakiewicz (2010): 45; por. Dudzik, Pisuliński (2006): 56, gdzie wyrażono trafny pogląd, że art. 239 k.c. należy zaliczyć do przepisów wyznaczających ramy prawa do zagospodarowania terenu, które korespondują z innymi, odnoszacymi się do tego zagadnienia uregulowaniami (np. art. 6 ust. 2 ustawy z 27 marca 2003 r. o planowaniu i zagospodarowaniu przestrzennym, t.jedn.: Dz. U. 2020, poz. 293).

8 Na podstawie art. 19 ust. 2 ustawy z 29 kwietnia 1985 r. o gospodarce gruntami i wywłaszczaniu nieruchomości, t.jedn.: Dz. U. 1991, Nr 30, poz. 127 ze zm. (dalej jako: u.g.g.).

9 Na podstawie art. 30 u.g.n.

10 Przeciwnie Dudzik, Pisuliński (2006): 53-54.

11 Tak SN w wyroku z 18 lutego 2015 r., I CSK 129/14, Lex nr 1645241; wyrok SA w Warszawie z 22 września 2017 r., I ACa 1013/16, Lex nr 2376953.

12 Zob. uzasadnienie uchwały składu 7 sędziów SN z 29 kwietnia 1985 r., III AZP 11/84, Lex 9489; oraz wyroki SN: z 11 marca 2011 r., II CSK 428/10, Lex nr 964462; z 6 czerwca 2012 r., III CSK 289/11, Lex nr 1164290.

13 Zgodnie z art. 221 ust. 3 u.g.n. o celu użytkowania wieczystego wnioskuje się właśnie ze sposobu korzystania z nieruchomości.

14 Wyrok SN z 7 października 2016 r., I CSK 327/15, Lex nr 2151393. 
pod budownictwo mieszkaniowe, w stosunku do których może znaleźć zastosowanie ustawa o przekształceniu prawa użytkowania wieczystego gruntów zabudowanych na cele mieszkaniowe w prawo własności tych gruntów i przekształcić je z mocy prawa w prawo własności ${ }^{15}$.

\section{ZMIANA SPOSOBU KORZYSTANIA Z GRUNTU JAKO ZDARZENIE MOGĄCE ZMIENIAĆ TREŚĆ UŻYTKOWANIA WIECZYSTEGO}

Rozdźwięk pomiędzy ustalonym celem użytkowania wieczystego a sposobem korzystania z gruntu prowadzi do dezaktualizacji umowy jako źródła stosunku prawnego użytkowania wieczystego. Warto w tym miejscu przywołać popierany w niniejszym tekście pogląd Sądu Najwyższego z 2017 r. ${ }^{16}$, w którym zwrócono uwagę na dwie płaszczyzny stosunku prawnego użytkowania wieczystego ${ }^{17}$. Po pierwsze, wskazano na stosunek rzeczowy, który wyraża się w aspekcie uprawnień użytkownika wieczystego wobec gruntu i jego pozycji względem osób trzecich. Po drugie, dostrzeżono, że w relacjach pomiędzy użytkownikiem wieczystym a właścicielem występuje element stosunku zobowiązaniowego dotyczący właśnie sposobu korzystania z gruntu. Z kolei podstawa obu aspektów tego stosunku prawnego jest umowa o oddanie gruntu w użytkowanie wieczyste. A ze względu na to, że sposób korzystania z gruntu jest powiązany z celem użytkowania wieczystego, zmiany w tej kwestii nie pozostaja bez wpływu na ten stosunek prawny, a w szczególności na więź obligacyjną pomiędzy właścicielem a użytkownikiem wieczystym.

Przepisy Kodeksu cywilnego oraz u.g.n. odnoszace się do użytkowania wieczystego nie regulują wprost możliwości modyfikacji umowy o oddanie gruntu w użytkowanie wieczyste. Jednakże nie może budzić większych wątpliwości dopuszczalność zmian treści umowy o oddanie gruntu w użytkowanie wieczyste z zachowaniem reguł wyrażonych $\mathrm{w}$ art. $353^{1}$ wraz z $77 \S 1$ k.c. Zagadnieniem wymagającym rozstrzygnięcia jest jednak to, czy faktyczne zachowanie użytkownika wieczystego może skutecznie zmodyfikować treść użytkowania wieczystego, zwłaszcza biorąc pod uwagę treść art. 73 ust. 2 u.g.n.

Sama już analiza art. 73 ust. 2 u.g.n. in fine dowodzi, że ustawodawca nadaje czysto faktycznemu i trwałemu zjawisku moc prawną aktualizujacca nie tyle treść użytkowania wieczystego w zakresie wysokości należnych opłat, ile obowiązek określonego działania po stronie właściciela gruntu. Zatem to nie zdarzenie faktyczne $\mathrm{w}$ postaci zachowania użytkownika wieczystego zmienia treść stosunku prawnego, lecz czynność prawna dokonana przez oddającego

15 Zob. art. 1 ust. 1 ustawy z 20 lipca 2018 r. o przekształceniu prawa użytkowania wieczystego gruntów zabudowanych na cele mieszkaniowe w prawo własności tych gruntów, Dz. U. poz. 1716.

16 Wyrok SN z 4 kwietnia 2017 r., I CSK 249/16, Lex nr 2305907 (dalej jako: SN z 2017 r.).

17 Aspekty stosunków obligacyjnych w relacjach prawnorzeczowych były już wcześniej dostrzegane, szerzej o tej problematyce Gniewek (2007): 25. 
grunt w następstwie tego zdarzenia. Jest to szczególnie widoczne, gdy wskazany przepis uzna się za podstawę do rekonstrukcji normy kompetencyjnej. Widać wówczas, że w przepisie tym występuje obowiązek (przymus ustawowy) podjęcia przez właściciela gruntu określonego zachowania, w tym przypadku złożenia użytkownika wieczystego oświadczenia woli o określonej treści. Należy wręcz uznać, że analizowany przepis stanowi materialną podstawę, która koresponduje z art. 64 k.c. w zw. z 1047 k.p.c. Z tym zastrzeżeniem, że niezbędne jest wcześniejsze wyczerpanie drogi administracyjnoprawnej określonej w art. 78-81 u.g.n. W przypadku nierozpoznania sprawy przez sąd powszechny taki skutek kształtujący będzie mieć rozstrzygnięcie samorzadowego kolegium odwoławczego (SKO) uwzględniające żądanie wieczystego użytkownika.

Na tym etapie rozważań trzeba wyraźnie wskazać, że chociaż zmiana sposobu korzystania z gruntu wpływa na cały stosunek prawny, to odrębnej ocenie podlegać będzie dopuszczalność zmiany z tego powodu wysokości stawki opłaty rocznej, którą odróżnić należy od dopuszczalności zmiany treści użytkowania wieczystego w zakresie celu w wyniku zmian w sposobie zachowania się użytkownika wieczystego. Podstawowym środkiem modyfikującym treść użytkowania wieczystego w zakresie wysokości opłaty rocznej jest nie umowa (czego oczywiście nie można wykluczyć), ale jednostronne oświadczenie kształtujące właściciela nieruchomości polegające na wypowiedzeniu dotychczasowej wysokości na podstawie wspomnianego już art. 73 ust. 2 w zw. z 78 u.g.n. $\mathrm{Z}$ kolei umowa będzie miała podstawowe i wyłączne znaczenie dla zaktualizowania treści umowy użytkowania wieczystego w zakresie celu. Jednakże nie jest możliwe dokonywanie zmian wysokości opłat rocznych wbrew określonemu pierwotnie celowi oddania gruntu w użytkowanie wieczyste. Oznacza to, że w pierwszej kolejności należy doprowadzić do zmiany umownej treści użytkowania wieczystego, jeżeli faktyczny sposób korzystania z gruntu uzasadniający nową stawkę nie koresponduje z celem użytkowania wieczystego. Taki pogląd uzasadniony jest również tym, że choć w prawie cywilnym faktyczne zachowania stron moga być, i w niektórych sytuacjach sa, zdarzeniami prawnie relewantnymi, to same nie moga, nawet w świetle art. 60 k.c., jednostronnie zmieniać treści umowy. Warto w tym miejscu dodać, że jeśli właścicielowi nie przysługuje uprawnienie do jednostronnego zniweczenia skutków nawiązanego stosunku prawnego, to tym bardziej podmiotowi, który z przedmiotu jego własności korzysta.

Fundamentalna dla prawa cywilnego zasada autonomii woli oraz rola samej umowy jako instrumentu dochodzenia do wspólnego consensusu pomiędzy stronami o przeciwstawnych interesach wymaga, aby w pierwszej kolejności na nowo uregulować stosunki na szczeblu o najogólniejszym spektrum oddziaływania na stosunek prawny, a następnie zmodyfikować szczegółowe rozwiązania zgodnie z nowymi realiami dla tej relacji prawnej. Zatem odróżnienie zmiany samego umownego celu użytkowania wieczystego od uzależnionej od tej modyfikacji wysokości opłat rocznych wymaga przyjęcia, że zmiana wysokości opłaty rocznej stanowi w zasadzie pochodną zmiany treści umowy o oddanie gruntu w użytkowanie wieczyste, która ma charakter nadrzędny 
i z która musi pozostawać w zgodzie. Nie jest jednak wykluczone, że cel zostanie w umowie tak określony, iż pozwoli na różne sposoby korzystania z gruntu, bądź o tym celu będzie decydować wyłącznie zachowanie użytkowania wieczystego, wówczas analizowany problem nie powstanie.

W sporach pomiędzy użytkownikiem wieczystym a oddającym grunt o wpływ zmiany sposobu korzystania na modyfikację treści użytkowania wieczystego nieocenione znaczenie ma stanowisko Sądu Najwyższego z 2012 r. ${ }^{18}$ Podstawowym walorem przywołanego orzeczenia jest stwierdzenie, że „literalna wykładnia art. 73 ust. 2 u.g.n. nie daje żadnych podstaw do uznania, że istnieje jedno formalne kryterium, na podstawie którego można przesądzić, o tym że mamy do czynienia ze zmianą sposobu korzystania z nieruchomości, która przybrała charakter trwały". Trudno wyobrazić sobie sytuację, aby zmiana celu, chociażby z działalności rekreacyjnej na cele mieszkaniowe, odbywała się w sposób mało oczywisty i konkludentny bez rażącego naruszania treści umowy o ustanowienie użytkowania wieczystego. Różnorodność stanów faktycznych uzasadniających stosowanie poszczególnych stawek z art. 72 ust. 3 u.g.n. wymaga wręcz konkretnych i jednoznacznych zachowań użytkownika wieczystego. Na tej podstawie należy przyjąć, że możliwość zmiany stawki procentowej dla opłat rocznych musi być poprzedzona ustaleniem czy legalnie zmieniono cel użytkowania wieczystego na skutek faktycznych zachowań użytkownika wieczystego.

\section{ZNACZENIE M.P.Z.P. PRZY ZMIANIE CELU UŻYTKOWANIA WIECZYSTEGO}

Kwestią nastręczająca wątpliwości jest dopuszczalność zmiany celu użytkowania wieczystego, a przez to i wysokości stawki dla opłaty rocznej, wbrew przeznaczaniu gruntu ustalonym w m.p.z.p. obowiązujacych dla terenu położenia gruntu ${ }^{19}$. Nietrudno sobie wyobrazić sytuację, gdy użytkownik wieczysty gruntu przeznaczonego w m.p.z.p. pod rekreację z opłatą roczną w wysokości $3 \%$ ceny nieruchomości będzie żądać zmiany celu użytkowania na mieszkaniowy z opłatą na poziomie $1 \%$ ceny nieruchomości. Ze względu na to, że cel jest elementem treści użytkowania wieczystego, należy przyjać, iż m.p.z.p. powinien być zawsze kryterium wstępnym oceny legalności zachowania użytkownika wieczystego, a także prawidłowości odpowiadającym im kontrdziałaniom właściciela gruntu. Znajduje to uzasadnienie w dwóch okolicznościach. Po pierwsze, w przeciwnym razie władztwo planistyczne gminy byłoby jedynie fikcja, gdyby działania natury faktycznej, choć sprzeczne z m.p.z.p., były w ten sposób legalizowane i wywoływały skutki prawne. Po drugie - jak wskazano już powyżej przy dokonywaniu zmian w treści użytkowania wieczystego właściwy organ musi zastosować tryb pisemnego wypowiedzenia określonego

${ }^{18}$ Wyrok SN z 22 marca 2012 r., IV CSK 333/11, Lex nr 1168729 (dalej jako: SN z 2012 r.).

${ }^{19}$ Zob. Szewczyk, Kruś (2018): 38-43 w kwestii pojęcia przeznaczenia terenu i jego źródeł. 
w art. 78-81 u.g.n. albo zawrzeć umowę zmieniającą. Obie czynności prawne muszą być zgodne z ustawa, zasadami współżycia społecznego oraz nie moga być dokonane in fraudem legem (art. 58 k.c.). W przypadku umowy istotna jest także treść art. $353^{1}$ k.c. zakładająca, że taka czynność prawna musi odpowiadać naturze (właściwości) stosunku. Po ostatnie, kwalifikacja m.p.z.p. jako aktów powszechnie obowiązujących ${ }^{20}$ nie sprzeciwia się również wąskiemu rozumieniu terminu „ustawa”21, które wiąże jego znacznie wyłącznie z aktem o charakterze generalnym oraz abstrakcyjnym majacych miejsce w strukturze źródeł prawa powszechnie obowiązującego wskazanego w art. 87 ust. 1 Konstytucji. Poprzeć bowiem należy pogląd, że ocena legalności czynności prawnej musi nastapić nie tylko na podstawie przepisów rangi ustawowej, lecz także z uwzględnieniem aktów niższego rzędu wydanych przez uprawniony podmiot w wykonaniu tej ustawy i w granicach ustanowionego tam upoważnienia ${ }^{22}$.

Podsumowując, każda czynność prawna sprzeczna z m.p.z.p. powinna być uznana w tym zakresie za nieważna, a działania faktyczne - za bezprawne.

\section{MOŻLIWE REAKCJE WŁAŚCICIELA GRUNTU NA NARUSZENIA TREŚCI UMOWY O ODDANIU GRUNTU W UŻYTKOWANIE WIECZYSTE}

\section{Skutki sprzeczności zachowania użytkowania wieczystego $\mathrm{z}$ treścią umowy o oddanie gruntu w użytkowanie wieczyste}

W przypadku korzystania z gruntu przez użytkownika wieczystego w sposób sprzeczny z treścią umowy można przyjąć, że właściciel nieruchomości oddanej w użytkowanie wieczyste ma trzy możliwości. Po pierwsze, właściciel gruntów publicznych może podjąć czynności zmierzające do rozwiązania umowy użytkowania wieczystego na podstawie art. 240 k.c. w zw. z 33 ust. 3 u.g.n. (wariant pierwszy). Po drugie, pod warunkiem zgodności z m.p.z.p., może zaakceptować ten stan i doprowadzić do odpowiednich zmian w zawartej umowie, w tym zmienić stawkę opłaty rocznej pobieranej za użytkowanie wieczyste zgodnie z art. 78-81 u.g.n. (wariant drugi). Po trzecie, pod warunkiem sprzeczności działań użytkownika wieczystego z m.p.z.p., oddający grunt w użytkowanie wieczyste może odmówić pobierania stawki w innej wysokości niż dotychczas ustalona oraz wstrzymać się z czynnościami zmierzajacych do rozwiązania umowy (wariant trzeci). Natomiast w sytuacji, gdyby sprzeczność między zachowaniem się użytkownika wieczystego a postanowieniami

20 Zob. o kwalifikacji m.p.z.p. wyrok TK z 20 kwietnia 2011 r., Kp7/09, OTK-A 2011, nr 3, poz. 26; Małysa-Sulińska (2018): 213; Niewiadomski (2018): kom. do art. 14, nb. 8; Parchomiuk (2017): 67; Szewczyk, Kruś (2018): 3637.

21 Zwłaszcza gdy chodzi o wykładnie terminu „ustawa” z art. 58 k.c., choć nie bez głosów sprzeciwu, por. Gniewek, Mikosz (2013): 400 i 431; Zbiegień-Turzańska (2013): nb. 17; Czarnik (2006): 42.

22 Zob. Radwański (2008): 229; Gutowski (2017): 231 n.; Machnikowski (2005): 183; Trzaskowski (2005): 203 n. 
m.p.z.p. nie kształtowała się w sposób oczywisty, przedstawiono dwa rozwiązania korygujące wyżej wskazany wariant trzeci poprzez próbę usunięcia występujących niezgodności (warianty adaptacyjne).

\section{Wariant pierwszy - rozwiązanie umowy}

Analiza przesłanek rozwiązania umowy o oddanie gruntu w użytkowanie wieczyste określonych w art. 240 k.c. i art. 33 ust. 3 u.g.n. może prowadzić do wątpliwości z ustaleniem podstaw do rozwiązania tej umowy ${ }^{23}$. Obie regulacje odnoszą się bowiem do potencjalnie różnych kryteriów. W art. 240 k.c. akcentuje się sprzeczność z przeznaczeniem gruntu, z kolei w art. 33 ust. 3 u.g.n. eksponuje się okoliczność sposobu korzystania z nieruchomości niezgodnie z ustalonym w umowie. Wskazana semantyczna różnica pomiędzy przywołanymi regulacjami nie prowadzi do sprzeczności, gdy uzna się, że przeznaczenie gruntu odpowiada celowi, jakiemu ma służyć nieruchomość, natomiast sposób korzystania z nieruchomości odnosi się do konkretnych czynności podejmowanych przez uprawnionego, które realnie manifestują przeznaczenie gruntu, a zatem sam cel $^{24}$. Z tego względu należy dojść do wniosku, że sposób korzystania z nieruchomości, przy braku szczególnych wymagań, musi co do zasady odpowiadać przeznaczeniu tej nieruchomości, ponieważ stanowi niejako jego pochodną ${ }^{25}$. W ten też sposób omawiane regulacje pozostają ze sobą w logicznym związku ${ }^{26}$.

Do rozwiązania umowy użytkowania wieczystego na podstawie art. 33 ust. 3 u.g.n w zw. z art. 240 k.c. konieczne jest ponadto wykazanie dodatkowej przesłanki wyrażającej się w oczywistej sprzeczności miedzy tymi stanami. Zgodzić się należy ze stanowiskiem doktryny i orzecznictwa, że kryterium „oczywistej sprzeczności” sposobu korzystania z nieruchomości nie oznacza tylko prostych naruszeń warunków umowy, ale dotyczy naruszeń ewidentnych, rażących i niczym nieusprawiedliwionych oraz połączonych ze szczególnym nasileniem złej woli użytkownika ukierunkowanej na złamanie warunków umowy ${ }^{27}$. Zatem rozwiązanie umowy ustanawiajaccej użytkowanie wieczyste zakłada badanie w każdej sprawie konkretnych okoliczności doty-

${ }_{23}$ Por. Pyrzyńska (1998): 64-65; Truszkiewicz (2006): 178; (2012): 18; Suliński (2018): 319, który rozważa kwestie dopuszczalności rozwiązania umowy o oddanie gruntu w użytkowanie wieczyste z powodu sprzeczności jej treści z planem zagospodarowania przestrzennego.

24 Zob. wyrok SN z 29 czerwca 2007 r. (I CSK 133/07, Legalis), zgodnie z którym określenie sposobu korzystania z gruntu oddawanego w użytkowanie wieczyste jest jednak ściśle powiązane z celem ustanowienia tego prawa. Oznaczony w umowie sposób korzystania z gruntu konkretyzuje ten cel. W tym ujęciu cel jest to planowy wynik każdego racjonalnego działania, to do czego się dąży i o co się zabiega, a sposób to konkretna, określona metoda, forma lub tryb wykonania, ujęcia czegoś.

25 Pyrzyńska (1998): 64-65; Truszkiewicz (2006): 178; (2012): 18.

26 SN w wyrokach: z 18 czerwca 2010 r., V CSK 414/09, Lex nr 630179; z 29 czerwca 2007 r., I CSK 133/07, Lex nr 508822; z 28 stycznia 2011 r., I CSK 132/10, Lex nr 848104; z 16 listopada 2012 r., III CSK 42/12, Lex nr 1293774; z 18 lutego 2015 r., I CSK 129/14, Lex nr 1645241.

27 Zob. Bończak-Kucharczyk (2018): nb. 4; Pietrzykowski (2018): nb. 1. Zob. też wyroki SN: z 18 lutego 2015 r., I CSK 129/14, Lex nr 1645241; z 18 czerwca 2010 r., V CSK 414/09; z 8 grudnia 2010 r., V CSK 168/10; z 26 stycznia 2011 r., I CSK 132/10. 
czących sposobu użytkowania gruntu przez użytkownika wieczystego i przyczyn sprzeczności korzystania z gruntu z jego przeznaczeniem ${ }^{28}$. Stąd nie każda czynność użytkownika wieczystego podjęta wbrew przeznaczeniu gruntu będzie uzasadniać rozwiązanie umowy.

\section{Wariant drugi i trzeci - alternatywne rozwiązania dla właściciela gruntu}

Brak spełnienia warunków rozwiązania umowy albo niedoprowadzenie pomimo ich wystapienia - do rozwiązania umowy, pozwalaja przejść do sygnalizowanych alternatywnych metod usankcjonowania analizowanej kwestii przez właściciela gruntów publicznych. Utrzymanie tego stosunku prawnego w dotychczasowym lub nowym brzmieniu zależy jednak od treści obowiązującego m.p.z.p. Powszechnie obowiązujące przepisy m.p.z.p. mogą jednak uniemożliwić zmianę nieaktualnej już treści umowy albo przynajmniej samej stawki opłaty rocznej. Jak już wyżej wyjaśniono, samo faktyczne zachowanie się użytkownika może być jedną z przesłanek, nawet konieczna, pozwalająca na zmianę treści użytkowania wieczystego, ale nigdy wystarczająca. Zazwyczaj konieczne będzie spełnienie dodatkowych kryteriów, zwłaszcza o charakterze walidacyjnym, które w pierwszej kolejności powinny rozstrzygać o zgodności postulowanych zmian z m.p.z.p. Na tej podstawie właściciel może skorzystać z wskazanego drugiego wariantu i doprowadzić do zmiany treści umowy o oddanie gruntu w użytkowanie wieczyste, a przez to zmienić wysokość stawki procentowej na odpowiadającą użytkownikowi wieczystemu. Jeżeli jednak żądania użytkownika wieczystego nie mają oparcia w powszechnie obowiązującym prawie, to właścicielowi gruntu pozostaje wariant pierwszy lub trzeci. Jednakże stany faktyczne moga nie kształtować się tak klarownie dla właściciela gruntu, aby skutecznie zmienić treść umowy. W tym świetle rysują się jeszcze dwie możliwe do wystapienia sytuacje, które wymagają wnikliwszej analizy. Obie związane są z całkowita albo częściową niezgodnością zmiany celu użytkowania wieczystego z obowiązujaccym m.p.z.p. (warianty adaptacyjne).

\section{WARIANTY KORYGUJĄCE NIEZGODNOŚĆ ZMIANY CELU UŻYTKOWANIA WIECZYSTEGO Z M.P.Z.P.}

\section{Propozycja usunięcia niezgodności zakładająca zawieranie lub krzyżowanie się celu nowego z dotychczasowym}

Wariant ten będzie opierać się na dosyć funkcjonalnym podejściu do treści art. 73 ust. 2 oraz 72 ust. 3 u.g.n., a także na założeniu, że oprócz celu podstawowego (przeważającego - przy wielości celów) użytkowania wieczy-

${ }^{28}$ Zob. wyroki SN: z 30 maja 2003 r., III CKN 1409/00, Lex nr 146438; z 18 czerwca 2010 r., V CSK 414/09; z 8 grudnia 2010 r., V CSK 168/10; z 28 stycznia 2011 r., I CSK 132/10; z 28 marca 2012 r., V CSK 163/11, Lex nr 1212826; z 16 listopada 2012 r., III CSK 42/12, Lex nr 1293774. 
stego będzie możliwe wyznaczenie celów pochodnych. Cele pochodne będą dotyczyć aktywności użytkownika wieczystego, które pozostają w zgodzie $\mathrm{z}$ celem podstawowym, dotyczą bowiem jednego z aspektów faktycznego korzystania z gruntu. Założono tutaj również, że użytkownik wieczysty spełnił wszelkie prawem przewidziane warunki do zmiany celu, z wyjątkiem zgodności z m.p.z.p. ${ }^{29} \mathrm{~W}$ nieobowiązującej już ustawie z 14 lipca 1961 r. o gospodarce terenami w miastach i osiedlach ${ }^{30}$, na podstawie której po raz pierwszy wprowadzono to prawo rzeczowe, związek użytkowania wieczystego z treścia m.p.z.p. był bardzo silny. Nieruchomości oddawano w użytkowanie wieczyste, jeżeli było to zgodne z celami ustalonymi w m.p.z.p., a w razie jego bra$\mathrm{ku}-\mathrm{z}$ wstępnie ustalonymi założeniami tego planu. W kolejnej nieobowiązujacej ustawie z 29 kwietnia 1985 r. o gospodarce gruntami i wywłaszczaniu nieruchomości ${ }^{31}$ wysokość opłaty rocznej za użytkowanie wieczyste zależało od przeznaczenia gruntu pod określony typ budownictwa ${ }^{32}$. Obecnie jednak ustawodawca odszedł od tak zakreślonych kryteriów i odnosi się już do okoliczności, które niekoniecznie są związane ze sposobem zabudowy gruntu i rolą m.p.z.p. Dla zobrazowania wyeksponowanej różnicy w podejściu ustawodawcy wystarczy przywołać art. 72 ust. 3 pkt 4 u.g.n., w którym mowa jest o oddaniu nieruchomości gruntowej między innymi na cele mieszkaniowe. Zaznaczyć należy, że przeznaczenie gruntu pod zabudowę mieszkaniową nie jest tożsame z jego przeznaczaniem na cele mieszkaniowe. Obecnie stosowane kryterium jest zakresowo szersze i zabudowa tego gruntu budynkiem mieszkalnym nie wyczerpuje wszystkich możliwych sytuacji, co oznacza, że grunt może nie być zabudowany budynkami pozwalajacymi na całoroczny pobyt ludzi, a nadal może zawierać się w celach mieszkaniowych. Najlepiej jest to widoczne przy stanach faktycznych, w których grunty sa w m.p.z.p. przeznaczone pod rekreację lub uzdrowiska, użytkownik wieczysty zaś zmierza do zmiany celu na mieszkaniowy. Zatem możliwe jest wystąpienie sytuacji jedynie częściowej sprzeczności z pierwotnie oznaczonym celem użytkowania wieczystego. Takie stanowisko poprzeć można per analogiam argumentami $\mathrm{z}$ orzecznictwa $\mathrm{w}$ sprawach związanych ze stosowaniem stawki dla podatku

29 Należy poprzeć pogląd wyrażony przez Bończak-Kucharczyk (2018): nb. 4, że jeżeli trwała zmiana sposobu korzystania z przedmiotu umowy nie koliduje z planem zagospodarowania przestrzennego i otoczeniem, to należy zmienić opłatę za użytkowanie wieczyste (art.73 ust. 2 u.g.n.).

30 T.jedn.: Dz. U. 1969, Nr 22, poz. 159.

31 Dz. U. 1991, Nr 30, poz. 127.

32 Art. 40: „1. Wysokość opłaty rocznej za użytkowanie wieczyste lub zarząd gruntu przeznaczonego pod budownictwo mieszkaniowe, oświatowo-wychowawcze, lecznicze i profilaktyki zdrowotnej oraz opieki społecznej i organizacji charytatywnych, a także gruntu zabudowanego domami mieszkalnymi, wynosi 1\% ceny ustalonej na podstawie art. 39. 2. Wysokość opłaty rocznej za zarząd gruntami oddanymi na cele obronności i bezpieczeństwa Państwa wynosi $0,3 \%$ ceny ustalonej na podstawie art. 39. Rada Ministrów, w drodze rozporządzenia, określi rodzaje gruntów, które uważa się za niezbędne na cele obronności i bezpieczeństwa Państwa. 3. Wysokość opłaty rocznej za użytkowanie wieczyste lub zarząd gruntu nie zabudowanego lub zabudowanego nie wymienionego w ust. 1 wynosi $3 \%$ ceny ustalonej na podstawie art. 39. Stawka procentowa opłaty może ulec podwyższeniu w drodze zarządzenia wojewody w odniesieniu do gruntów stanowiących własność Skarbu Państwa lub uchwały rady gminy w odniesieniu do gruntów stanowiących własność gminy". 
od nieruchomości w przypadku budynków wypoczynkowych lub rekreacyjnych, które pod pewnymi warunkami uznaje się za mieszkalne ${ }^{33}$. Prowadzi to do jednego wniosku. W przypadku niezgodności z m.p.z.p. konieczne jest precyzyjne odróżnienie aspektów materialnych użytkowania wieczystego od aspektów fiskalnych z tym użytkowaniem związanych. W konsekwencji dla użytkowników wieczystych, od których pobierany jest podatek od nieruchomości wedle stawek dla nieruchomości mieszkalnych, należy także pobierać opłatę od użytkowania wieczystego gruntu na cele mieszkaniowe ${ }^{34}$. Ważne jest tutaj jednak to, że przy tak zarysowanym podejściu nie ma w ogóle mowy o zmianie sposobu korzystania, które wpływa na cel użytkowania wieczystego. Chociaż celem użytkowania wieczystego może być wzniesienie budynków letniskowych lub sanatoryjnych oraz ich utrzymanie, to funkcja rekreacyjna (cel podstawowy, dominujący) nie wyłącza funkcji mieszkaniowej (cel pochodny). Nie jest również wykluczone, że organ administracji architektoniczno-budowlanej, wydajacc zezwolenia na budowę lub rozbudowę budynków, będzie wskazywać funkcję mieszkaniową bądź takie stwierdzenie znajdzie się w ewidencji gruntów i budynków na skutek aktualizacji danych przez geodetę. Nie wspominając już o możliwości meldunku w takich obiektach. Skutkiem odróżnienia zagadnień fiskalnych od materialnych jest również to, że chociaż od użytkowników wieczystych będzie pobierana mniejsza stawka za użytkowanie wieczyste, to nie będą mogli wywodzić z tego faktu innych korzystnych dla siebie rozstrzygnięć prawnomaterialnych uzależnionych od celów mieszkaniowych. Wiąże się to głównie z możliwością przekształcenia użytkowani wieczystego w prawo własności. Ponadto w tym przypadku ingerencja w treść umowy o oddanie gruntu w użytkowanie wieczyste w zakresie innym niż wysokość opłaty rocznej będzie kwalifikowana jako nieważna ze względu na sprzeczność z m.p.z.p.

Podsumowując, wskazana na początku propozycja będzie miała zastosowanie do tych wszystkich stanów faktycznych, w których cel odpowiadający użytkownikowi wieczystemu będzie w pewnym sensie pochodna przeznaczenia nieruchomości w m.p.z.p. (np. wspomniany już cel rekreacyjny z celem mieszkaniowym). Ta koncepcja nie sprawdzi się zatem wszędzie tam, gdzie cele będą się wykluczać (np. nieruchomość przeznaczona będzie pod usługi turystyki i rekreacji [stawka 2\%], a użytkownik wieczysty będzie starać się wykazać cel w postaci niezarobkowej działalności leczniczej [stawka 0,3\%]).

${ }^{33}$ Zob. wyrok WSA w Szczecinie z 11 maja 2005 r. (I SA/Sz 501/04, Lex nr 806105), w którym Sąd przyjął słownikowe znaczenie tego pojęcia jako budynku służącego lub nadającego się do mieszkania oraz ustalił, że „mieszkać” oznacza „przebywać gdzieś stale lub czasowo, zajmować jakiś lokal, mieć mieszkanie, zamieszkiwać”; oraz uchwałę 5 sędziów NSA w Warszawie z 1 lipca 2002 r., FPK 2/02, Lex nr 54859, w którym stwierdzono, że o zaliczeniu budynku letniskowego do kategorii budynków mieszkalnych w rozumieniu art. 5 ust. 1 pkt 1 ustawy z 12 stycznia 1991 r. o podatkach i opłatach lokalnych (Dz. U. 2002, Nr 9, poz. 84 ze zm.) decyduje kryterium zaspokojenia podstawowych potrzeb mieszkaniowych właściciela i osób mu bliskich.

${ }^{34}$ Co do charakteru opłat z tytułu użytkowania wieczystego zob. Truszkiewicz (2012): 31. 


\section{Propozycja rozwiązania niezgodności między przeznaczaniem wynikającym z m.p.z.p. a nowym celem użytkowania wieczystego przy wzajemnym ich wykluczaniu się}

W tym wariancie ustalenie, że doszło do trwałej zmiany korzystania z gruntu w taki sposób, że modyfikacji uległ sam cel użytkowania wieczystego stanowić będzie okoliczność stawiająca użytkownika wieczystego w wysoce niekorzystnej sytuacji. Niedostrzeżenie przez użytkownika wieczystego treści obowiąującego m.p.z.p. prowadzi do zaznaczonych już komplikacji prawnych przy rozstrzyganiu spraw o zmianę tych stawek ${ }^{35}$. Otóż niewykluczone jest, że sporny grunt zgodnie z m.p.z.p. zostaje przeznaczony na przykład pod zabudowę usługowo-mieszkaniowa. W takiej sytuacji zmiana korzystania z celu usługowego na cel mieszkalny, przy takiej treści m.p.z.p. jest jak najbardziej możliwa. Zupełnie inaczej sprawa wygląda, gdy od samego początku obowiązuje m.p.z.p., który jednoznacznie przesądza przeznaczenie terenu. Jest to okoliczność kluczowa dla niniejszych rozważań. Przede wszystkim potwierdzając stanowisko użytkownika wieczystego, że skutecznie zmieniono cel użytkowania wieczystego, nie uwzględniając przy tym m.p.z.p., nałoży się na właścicieli nieruchomości publicznych obowiązek podjęcia działań z góry niemożliwych do wykonania. Nie będzie bowiem możliwe wykreowanie nowej więzi zobowiązaniowej, która od samego początku sprzeciwia się treści obowiązującego m.p.z.p. ${ }^{36}$

Można ponadto dodać, że nałożenie na właściciela gruntu obowiązku zmiany treści umowy o oddanie gruntu w użytkowanie wieczyste wbrew postanowieniom m.p.z.p. będzie obiektywnie niemożliwe do realizacji, a zatem taka czynność nie wywoła zamierzonych skutków prawnych, ponieważ zastosowania znajdzie art. 387 k.c.

Prowadzi to do wysoce niekorzystnego wniosku dla użytkowników wieczystych. Podejmowanie przez użytkownika wieczystego wszelkich czynności zmierzających do pozytywnego dla siebie rozstrzygnięcia przez SKO lub sąd powszechny prowadzi do udowodnienia, że spełniono wszelkie przesłanki uprawniajace do rozwiązania umowy użytkowania wieczystego na podstawie art. 33 ust. 3 u.g.n. w zw. z art. 240 k.c., w szczególności w zakresie naruszenia oczywistego, ewidentnego i niczym nieusprawiedliwionego oraz połączonego ze szczególnym nasileniem złej woli użytkownika ukierunkowanej na złamanie warunków umowy.

Poza tym warto wspomnieć o treści art. 33 ust. 2 u.g.n. Zgodnie z tym przepisem w razie wygaśnięcia użytkowania wieczystego na skutek rozwiązania umowy przed upływem okresu po stronie użytkownika wieczystego powstaje roszczenie o zapłatę wynagrodzenia za wzniesione przez niego lub

35 Sytuacja może się również przedstawiać zupełnie inaczej, zwłaszcza gdy uchwalono nowy plan zagospodarowania przestrzennego. Zob. Zięty (2011): 48 n.

${ }^{36}$ Umowa zmieniająca użytkowanie wieczyste nie może naruszać art. 58 k.c. oraz $353^{1}$ k.c., które w pierwszej kolejności wymagają zgodności z ustawą. W rezultacie niedopuszczalna jest zmiana zawartych umów użytkowania wieczystego z obowiązującym na tym terenie planem zagospodarowania przestrzennego. Nie można pomijać znaczenia aktów planowania, które skutecznie ograniczają także uprawnienia właścicieli w sposobie korzystania z należących do nich gruntów. 
nabyte na własność budynki i inne urządzenia. Jednakże za budynki i inne urządzenia wzniesione wbrew postanowieniom umowy, a które z założenia miały dowodzić zmiany celu umowy, wynagrodzenie nie będzie przysługiwać. Biorąc pod uwagę, że cechą charakterystyczną użytkowania wieczystego jest jego celowość z uwzględnieniem oddania gruntu zabudowanego określonym typem obiektów do utrzymania albo właśnie do konkretnego zabudowania, a także to, że wszelkie modyfikacje tych konstrukcji były dokonywane na cele inne niż wynikające z umowy, to nie będzie podstaw do wypłaty ewentualnych wynagrodzeń. Jednakże zaznaczyć trzeba, że prawidłowość tego wniosku wymaga przeanalizowania wszelkich pozwoleń budowlanych na nadbudowanie lub dobudowanie do istniejących konstrukcji nowych pomieszczeń lub kondygnacji. Nie jest wykluczone, że procesy budowlane dotyczyły obiektów, które jednak pozostają w zgodzie z celem użytkowania wieczystego (cel rekreacyjny, a zakres robót budowlanych dotyczących rozbudowy budynków mieszkalnych). Nie sprzeciwia się to jednak możliwości podniesienia przez właściciela gruntu zarzutu nadużycia prawa podmiotowego z art. 5 k.c. w myśl volenti non fit iniuria przeciw użytkownikowi wieczystemu, który zdając sobie sprawę z przeznaczenia terenu oraz treści umowy użytkowania wieczystego, intencjonalnie podejmował inwestycje na gruncie, aby zmienić sposób korzystania z nieruchomości, a tym samym dąży do zmiany celu użytkowania wieczystego, z którego chciał wywodzić dla siebie korzystne skutki.

Powyższy wniosek nabiera znaczenia zwłaszcza w kontekście następstw wspomnianej już ustawy o przekształceniu prawa użytkowania wieczystego gruntów zabudowanych na cele mieszkaniowe w prawo własności tych gruntów. Nie jest bowiem wykluczone, że użytkownik wieczysty gruntu oddanego na cele usługowe wzniesie budynek, w którym jedynie parter będzie przeznaczony pod usługi, reszta kondygnacji zaś będzie składać się z lokali mieszkalnych, co potencjalnie pozwoli na spełnienie kryteriów z art. 1 ust. 2 pkt 2 tej ustawy ${ }^{37}$. Oczywiście, jeśli dopuści się możliwość zmiany treści użytkowania wieczystego, co w świetle przedstawionych wyżej argumentów będzie jawić się jako wątpliwe.

Szymon Stotwiński

Uniwersytet Szczeciński

szymon.slotwinski@usz.edu.pl

https://orcid.org/0000-0002-9763-6747

Bończak-Kucharczyk, E. (2018). Ustawa o gospodarce nieruchomościami. Komentarz. Wydanie 5. Lex/el.

Cisek, A. (2007). Użytkowanie wieczyste, [w:] E. Gniewek (red.), System prawa prywatnego. Tom 4: Prawo rzeczowe. Warszawa: 142-232.

Czarnik, Z. (2006). Miejscowy plan zagospodarowania przestrzennego jako podstawa wykonywania własności nieruchomości. Zeszyty Naukowe Sądownictwa Administracyjnego 2(5): 42-50.

37 Zgodnie z tym przepisem grunty zabudowane na cele mieszkaniowe to takie nieruchomości, które zabudowano wyłącznie budynkami mieszkalnymi wielorodzinnymi, przy czym co najmniej połowę liczby lokali stanowić mają lokale mieszkalne. 
Dudzik, S., Pisuliński, J. (2006). Określenie sposobu korzystania z gruntu w umowie o oddanie gruntu w użytkowanie wieczyste - konsekwencje dla procesu inwestycyjnego. Samorząd Terytorialny 16(5): 49-60.

Gniewek, E., Mikosz, R. (2013). Treść i wykonywanie prawa własności, [w:] E. Gniewek (red.), System prawa prywatnego. Tom 3: Prawo rzeczowe. Warszawa: 338-442.

Gutowski, M. (2017). Nieważność czynności prawnej. Warszawa.

Machnikowski, P. (2005). Swoboda umów według art. $353^{1}$ KC. Konstrukcja prawna. Warszawa.

Małysa-Sulińska, K. (2018). Informacja na temat przeznaczenia terenu oraz warunków jego zabudowy i zagospodarowania ujęta w aktach kształtujących ład przestrzenny, [w:] A. Walaszek-Pyzioł (red.), Informacje gospodarcze. Studium prawne. Warszawa: 211-228.

Niewiadomski, Z. (2016). Kom. do art. 6, [w:] Z. Niewiadomski (red.), Planowanie i zagospodarowanie przestrzenne. Komentarz. Wydanie 9. Legalis: nb. 10.

Parchomiuk, J. (2017). Przesłanki dopuszczalności ograniczeń własności zabytków w świetle konstytucyjnych i konwencyjnych standardów ochrony własności. Roczniki Nauk Prawnych 27(3): 63-89.

Pietrzykowski, K. (2018). Kom. do art. 240, [w:] K. Pietrzykowski (red.), Kodeks cywilny. Tom 1: Komentarz. Art. 1-449 ${ }^{10}$. Wydanie 9. Legalis: nb. 1.

Pyrzyńska, A. (1998). Rozwiązanie umowy użytkowania wieczystego. Rejent 10(90): 52-71.

Radwański, Z. (2008). Treść czynności prawnej, [w:] Z. Radwański (red.), System prawa prywatnego - część ogólna. Tom 2. Warszawa: 224-283.

Sanakiewicz, Ł. (2010). Przeniesienie użytkowania wieczystego w drodze umowy przekazania. Rejent 1(225): 99-133.

Suliński, G. (2018). Rozbieżność pomiędzy sposobem korzystania z gruntu określonym w umowie o oddanie nieruchomości gruntowej w użytkowanie wieczyste a jej przeznaczeniem określonym w miejscowym planie zagospodarowania przestrzennego, [w:] A. Walaszek-Pyzioł (red.), Informacje gospodarcze. Studium prawne. Warszawa: 311-322.

Szewczyk, M., Kruś, M. (2018). Plan miejscowy a decyzja o warunkach zabudowy. Zeszyty Naukowe Sądownictwa Administracyjnego 14(2): 35-51.

Truszkiewicz, Z. (2006). Użytkowanie wieczyste. Kraków.

Truszkiewicz, Z. (2012). Użytkowanie wieczyste, [w:] E. Gniewek (red.), System prawa prywatnego. Tom 4: Prawo rzeczowe. Warszawa: 2-103.

Trzaskowski, R. (2005). Granice swobody kształtowania treści i celu wmów obligacyjnych (art. $353^{1}$ K.C.). Kraków.

Woźniak, C. (2006). Użytkowanie wieczyste. Warszawa.

Zbiegien-Turzańska, A. (2015). Kom. do art. 239, [w:] K. Osajda (red.), Kodeks cywilny. Komentarz. Beck Online Komentarze. Legalis: nb. 1.

Zbiegień-Turzańska, A. (2013). Kom. do art. 140, [w:] K. Osajda (red.), Kodeks cywilny. Komentarz. Beck Online Komentarze. Legalis: nb. 17.

Zięty, J. (2011). Roszczenia właściciela oraz użytkownika wieczystego nieruchomości związane z uchwaleniem lub zmianą miejscowego planu zagospodarowania przestrzennego oraz wydaniem decyzji o warunkach zabudowy bądź lokalizacji inwestycji celu publicznego. Samorząd Terytorialny 21(4): 48-62.

\section{THE RESULTS OF CHANGING THE METHOD OF \\ USING THE REAL ESTATE PUT INTO PERPETUAL USUFRUCT \\ IN OPPOSITION TO THE PURPOSE SET OUT IN THE CONTRACT \\ AND THE PURPOSE OF THE LAND RESULTING FROM THE AREA DEVELOPMENT PLAN}

\section{Sum mary}

The following paper addresses two issues. First, it focuses on the assessment of the legality of changing the perpetual usufruct through the actual behaviour of the user, with particular consideration of the provisions of the area development plan. The considerations start with the legal qualification of the purpose and its meaning for the perpetual usufruct, which is a point of refer- 
ence for further analysis. In this regard, the article attempts to show that the actual action of the perpetual user is not an event modifying the perpetual usufruct, but is rather a premise for the competences of the relevant authorities to make changes to the content of this legal relationship. Legal actions undertaken in this matter must be compliant with the generally applicable law, in particular with the relevant spatial development plan. Second, efforts were made to indicate the scope of a landowner's legally permissible reaction to the action of the perpetual usufructuary that would change this legal relationship. Options are analysed, starting from contract termination to modifications. The paper concludes with some proposed solutions which could solve the contradiction of the perpetual user's behaviour with the analysed standards, when it does not take on an obvious character.

Keywords: perpetual usufruct; change of purpose; zoning plan 
